\title{
OVERVIEW
}

\section{Biology and ecology of sawfishes: global status of research and future outlook}

\author{
Gregg R. Poulakis ${ }^{1, *}$, R. Dean Grubbs ${ }^{2}$ \\ ${ }^{1}$ Fish and Wildlife Research Institute, Florida Fish and Wildlife Conservation Commission, \\ Charlotte Harbor Field Laboratory, Port Charlotte, Florida 33954, USA \\ ${ }^{2}$ Florida State University Coastal and Marine Laboratory, St. Teresa, Florida 32358, USA
}

\begin{abstract}
Globally, sawfishes are threatened with extinction because they occur in coastal habitats, which are disproportionally affected by human activities. In particular, sawfishes are susceptible to myriad fisheries that operate in the same regions. Unfortunately, these well-documented threats can be only partly mitigated because of ongoing human resource needs. However, the outlook for sawfishes is optimistic if we build on 5 successful research and conservation approaches developed over the past 2 decades: (1) local ecological knowledge, (2) identification of nurseries, (3) state-of-the-art techniques, (4) tagging studies, and (5) threat mitigation. If appreciation of healthy ecosystems that contain top predators like sawfishes can be fostered by healthy human populations where sawfishes occur (e.g. ecosystem management, promotion of sustainable livelihoods), and if local knowledge can be used to influence scientific studies that inform customized management decisions, this group of iconic species will have a chance to recover. In addition, promoting sample collection, sample archiving, and collaboration, especially in instances of sawfish mortality, will maximize the knowledge gained, despite often limited funding and limited samples. The first 2 decades of the 21st century have seen the first steps taken toward sawfish recovery, but there is more to do. Ultimately, translation of research results into conservation actions that include enforcement and fisher behavior change will be the key to sustained recovery. This Overview provides a context for the papers in the Theme Section 'Biology and ecology of sawfishes', and we incorporate them as part of a mini-review of research on this threatened group to provide a future outlook.
\end{abstract}

KEY WORDS: Conservation - Local ecological knowledge $\cdot$ Behavior change $\cdot$ Ecosystem management $\cdot$ Nursery $\cdot$ Acoustic tagging and monitoring $\cdot$ Genetics $\cdot$ Environmental DNA

\section{INTRODUCTION}

Sawfishes belong to a family of large, shark-like rays that occur at low latitudes, and populations of all 5 species have declined to the point that they are among the most threatened fishes in the world (Dulvy et al. 2014). Most species were not studied prior to population declines and so are poorly understood biologically and ecologically; however, conservation-focused research efforts have expanded over

${ }^{*}$ Corresponding author: gregg.poulakis@myfwc.com the past decade. Globally, these research efforts have provided (1) new insights into the current distribution, biology, and ecology of sawfishes, and (2) guidance toward achieving species' recoveries (e.g. NMFS 2009, Fordham et al. 2018).

From its inception in 1985 at its first meeting in Knoxville, Tennessee, at which Dr. Thomas Thorson was the keynote speaker, the American Elasmobranch Society has played a key role in sawfish research and conservation. As part of a large work

() The authors 2019. Open Access under Creative Commons by Attribution Licence. Use, distribution and reproduction are unrestricted. Authors and original publication must be credited. 
focused on the ichthyofauna of Nicaraguan lakes, Dr. Thorson was the first researcher to study the biology of a sawfish in detail (Thorson 1976). At that time, the connectivity of Lake Nicaragua to the Atlantic Ocean was not well understood, but he documented sawfish movements within the lake and between the lake and the ocean through his tagging research (Thorson 1982a). He took advantage of a sawfish and shark fishery in Lake Nicaragua to document the reproductive biology of the largetooth sawfish Pristis pristis, while sounding the alarm about the unsustainability of the fishery (Thorson 1976, 1982b).

Not surprisingly, the fishery in Lake Nicaragua collapsed by the mid-1980s, and concurrently, global declines in sawfish populations began to be noticed by a variety of regional organizations. It was too late for Lake Nicaragua, but multiple conservation actions followed in developed parts of the world. Early protections and listings included prohibition of sawfish harvest by the State of Florida, USA, in 1992, protection in Western Australia state waters by the Fish Resources Management Act in 1994, and the listing of 4 sawfish 'species' as Endangered or Critically Endangered on the IUCN Red List of Threatened Species by the IUCN Species Survival Commission Shark Specialist Group (SSG) in 1996 (IUCN 1996, FWC 1999). At that time, so little research had been conducted on sawfishes that the taxonomy of the family was poorly understood, but 5 extant species are now recognized (Faria et al. 2013). Taxonomic resolution allowed species-specific assessments and research to proceed and be published (e.g. Chapman et al. 2011, Carlson et al. 2013, Kyne et al. 2013, Simpfendorfer 2013), including updates to large ichthyofaunal works that helped clarify some of the historical literature on topics such as species ranges and life-history traits (e.g. Last \& Stevens 2009).

Efforts to champion the plight of sawfishes and bring researchers together began at about the time the smalltooth sawfish Pristis pectinata was added to the US Endangered Species List, which occurred on 1 April 2003 (NMFS 2003). That year, a symposium titled 'Sawfish: threats, biology, and conservation in the 21st century' was organized for the 19th annual meeting of the American Elasmobranch Society in Manaus, Brazil. The symposium featured 8 presentations: 1 on their global status, 5 from the USA, and 2 from Australia, reflecting the 2 countries where most sawfish research and recovery efforts were underway. A 2012 meeting organized by the IUCN SSG led to the production of a global conservation strategy for sawfishes (Harrison \& Dulvy 2014). Another sawfish- focused symposium featuring 9 presentations was held in 2014 at the 2nd Sharks International meeting in Durban, South Africa. Since those symposia, research has increased and many collaborations have developed, an ongoing online issue of the journal Aquatic Conservation began, and the Sawfish Conservation Society (http://sawfishconservationsociety. org) was founded. In 2017, the IUCN SSG organized a meeting to evaluate conservation progress in the 5 yr since the meeting that produced the global conservation strategy. One of the main findings was that sawfish research was underway in at least 35 of the 78 countries where sawfishes historically occurred and they are specifically protected in 19 of the 36 countries where sawfish populations are known to still occur (Fordham et al. 2018).

In 2016, a symposium at the 32nd annual meeting of the American Elasmobranch Society in New Orleans, Louisiana, brought together many of the world's sawfish researchers to share their latest findings and promote future collaborations. The symposium included nearly 40 presentations representing 14 countries and all 5 species. Based on this symposium, we compiled a Theme Section for Endangered Species Research titled 'Biology and ecology of sawfishes'. Topics ranged broadly from summaries of the knowledge of local fishers in under-studied regions (e.g. Africa, the Middle East, Papua New Guinea, South America) and the role of public aquaria in sawfish conservation, to research on sawfish ecology, physiology, and population genetics. As an overview of this body of research papers, we incorporate them as part of a mini-review of research on this threatened group to provide a future outlook.

\section{STATUS OF RESEARCH AND FUTURE OUTLOOK ON THE BIOLOGY, ECOLOGY, AND CONSERVATION OF SAWFISHES}

\subsection{Local ecological knowledge and identification of nurseries}

Often, besides scouring the literature and museum collections for reliable records (e.g. White et al. 2017 this Theme Section), a first step toward assessing the status of sawfishes involves collecting historical and contemporary data from fishers in an area of interest, usually with a standardized questionnaire. These data have been referred to by several names, such as local ecological knowledge (LEK), traditional ecological knowledge (TEK), and public encounter reports (Sáenz-Arroyo et al. 2005, Pinnegar \& Engelhard 
2008). Since artisanal, commercial, and recreational fishing activities occur in almost all coastal waters, people who engage in these activities are often a good source of information on fishes, especially easily recognizable species like sawfishes, because there are many more fishers than scientists. In the past 2 decades, this approach has been used in many regions where sawfishes are found, or were thought to historically occur, and has helped (1) determine areas of historical occurrence, (2) avoid erroneous designation of local extinctions, (3) determine areas in which they still occur, (4) determine areas in which they are locally extinct or never occurred, (5) prioritize where to focus scientific research and management efforts, and (6) in the USA, as required by the Endangered Species Act, establish recovery criteria and juvenile critical habitat areas, which are purely management designations and spatially broader than documented nurseries (e.g. Seitz \& Poulakis 2002, NMFS 2009, Norton et al. 2012, Hossain et al. 2015). Most recently, this approach has been used in Argentina, Brazil, Mexico, Papua New Guinea, Sudan, Gambia, UAE, and Uruguay (e.g. Reis-Filho et al. 2016, Jabado et al. 2017, Manir Feitosa et al. 2017, Bonfil et al. 2018, Elhassan 2018, Leeney et al. 2018, Cuevas et al. 2019, all in this Theme Section, and Leeney \& Downing 2016, Bonfil et al. 2017). Use of data obtained from fishers is ongoing and will be a rich resource for protecting remaining sawfish populations and promoting recovery. Environmental DNA (eDNA) studies have emerged in recent years and may be able to build on encounter-derived data, especially in remote locations, if important methods details can be adequately addressed a priori (see Section 2.2.2).

Sawfish-reporting phone numbers, email addresses, signage at boat ramps and fishing piers, websites, and social media networks help establish, promote, and maintain communication between the public, scientists, and managers. Sawfish records provided by fishers can be plotted on maps to help identify and protect important habitats such as nursery areas, an important step in research and conservation. Often, these data will be the first of multiple lines of evidence used to document areas of occurrence that can be used for specific management actions, such as the establishment of juvenile critical habitats in the USA (Norton et al. 2012), and perhaps locate the last-remaining nurseries associated with some populations. The encounter data have been used to direct scientific research and allow local authorities to make informed decisions about development projects and habitat restoration opportunities
(Poulakis et al. 2011, National Marine Fisheries Service [NMFS] pers. comm., The Nature Conservancy pers. comm.). For example, intra-nursery areas of high use, i.e. the most productive habitat patches within the nursery (Nagelkerken et al. 2015), that is nursery hotspots (Poulakis et al. 2011, 2016) have been identified in multiple smalltooth sawfish Pristis pectinata nurseries, some of which have already been, and will continue to be, protected from habitat loss, thanks in large part to initial clues in fisherderived data (Huston et al. 2017, Scharer et al. 2017, Hollensead et al. 2018, all in this Theme section, and Poulakis et al. 2011, 2013, Hollensead et al. 2016, NMFS pers. comm.).

It is noteworthy that smalltooth sawfish nursery hotspots are small areas within the broader nurseries where young-of-the-year and age-1 juveniles commonly occur over many years (i.e. the most productive habitat patches within the nursery; Nagelkerken et al. 2015). Regardless of terminology (Heupel et al. 2018), it is our hope that readers will understand that all portions of smalltooth sawfish nurseries are not used equally and that the distinct areas of most intense use (Poulakis et al. 2011, 2016, Scharer et al. 2017) are the highest priority for management actions (NMFS pers. comm.). It is important to be clear that the existence of these hotspots does not restrict nursery designations to these areas of most intense use. In fact, the broader nurseries that were identified for the smalltooth sawfish by applying the Heupel et al. (2007) criteria seem to be adequate (Norton et al. 2012), so the hotspot concept and nursery criteria are complementary.

Interdisciplinary, collaborative, habitat-use studies and detailed biological and ecological questions have been answered as part of research published in this Theme Section as a result of long-term surveys conducted within nurseries, especially regarding the smalltooth sawfish (Feldheim et al. 2017, Huston et al. 2017, Morgan et al. 2017, Poulakis et al. 2017, Scharer et al. 2017, Whitty et al. 2017, Bakenhaster et al. 2018, Hollensead et al. 2018, Prohaska et al. 2018, all in this Theme Section). In addition to identifying geographic regions in which nurseries still exist, near-real-time, fisher-derived data have also been used to maximize tagging efforts, because juveniles exhibit high degrees of site fidelity. It is hoped that similar studies can be conducted in all places where sawfishes need protection, like Papua New Guinea, that have emerged as potential strongholds for remaining populations of the other 4 sawfish species, but currently have no protective measures in place (White et al. 2017, Green et al. 2018, Leeney et 
al. 2018, all in this Theme Section). A preliminary roadmap exists from the public-research-management approach that is working for the smalltooth sawfish, and this model may be able to be modified to fit the needs of other species.

\subsection{Demography and use of state-of-the-art techniques}

\subsubsection{Modern techniques}

Modern techniques, especially those in genetics, have been instrumental in answering questions about sawfishes related to biology, ecology, and recovery potential. Sources of DNA generally include thumbnail-size fin clips taken during research encounters or dried rostra that are common curios in private collections and museums (Phillips et al. 2009, Seitz \& Hoover 2017 this Theme Section). For example, because most sawfish populations have declined dramatically, one of the first questions that needs to be answered about a population is whether there is or was a genetic bottleneck. Sometimes, when populations of organisms decline severely, genetic diversity is compromised and populations can become inbred, which is problematic for recovery. Studies in the USA and Australia have shown generally high genetic diversity despite precipitous declines (Chapman et al. 2011, Phillips et al. 2017 this Theme Section), which should provide optimism for recovery, although in Australia, some assemblages of Pristis and Anoxypristis sawfishes may have experienced population bottlenecks or founder effects at some time (Phillips et al. 2017, Green et al. 2018).

Collecting and archiving DNA from all sawfishes encountered, and preserving their parts (e.g. organs, vertebrae), is recommended, and using subsamples in future studies will maximize what can be learned from the original samples. These samples can be used to answer a variety of questions related to biology and ecology, and archiving is important because it may take many years to collect enough samples to conduct research. High-quality, $95 \%$ ethanol is recommended for long-term storage of thumbnail-size samples for genetic analyses, and care should be taken to avoid desiccation of samples due to the volatility of ethanol and to avoid cross-contamination during the subsampling process (e.g. rinse the scissors with bleach, then with autoclaved deionized water between samples). If available and possible, larger samples from necropsies should be preserved in $10 \%$ buffered formaldehyde as quickly as possible, or as a last resort, frozen for archiving. Because of the large size that can be attained by sawfishes, care should be taken to ensure adequate fixation by using small enough subsamples and large enough containers. Developing a necropsy datasheet that linked samples, including preservation techniques, to collaborators has maximized what has been learned from smalltooth sawfish necropsies in Florida, USA, on topics such as age and growth, reproduction, and parasitology (e.g. Scharer et al. 2012, Kritsky et al. 2017, Poulakis et al. 2017, Bakenhaster et al. 2018).

Little is known about the biology of most sawfish species. For example, how often do females reproduce and how many offspring are born in each reproductive cycle? Answering these basic questions is vital for estimating recovery time, and DNA analyses can be used instead of traditional examinations of the reproductive tracts of many individuals, which is impractical when studying rare species. Feldheim et al. (2017) reconstructed parental genotypes using smalltooth sawfish DNA from the fin clips of juveniles collected over 12 consecutive years. This technique allowed construction of a time series whereby a biennial maternal reproductive cycle was documented even though young were captured every year. If sample collection is robust, these techniques can even be used to estimate brood size, as has been done for some elasmobranchs, including the smalltooth sawfish (Feldheim et al. 2004, DiBattista et al. 2008, Feldheim et al. 2017).

Little is known about the ecology of most sawfishes, including their feeding habits. Knowing what organisms sawfishes rely on as prey is an important part of the recovery process, especially since their growth rates can be fast during early life history (Scharer et al. 2012). Because of the small sample size, traditional stomach content analyses are difficult to conduct on endangered species (e.g. necropsies, gastric lavage), but analyses of stable isotopes of carbon and nitrogen from tissue or blood samples and DNA analyses of opportunistically collected fecal samples have been used to gain insights into diet (Thorburn et al. 2014, Poulakis et al. 2017). Stable isotope analyses are useful for learning about what the sawfishes are assimilating into their bodies, and stomach contents, feces, and other opportunistic samples (e.g. scales attached to rostral teeth) can be used to validate the stable isotope results (Poulakis et al. 2017). Further, general characterizations of prey assemblages at relatively low taxonomic resolution can be determined using 18S rRNA techniques, and, to better elucidate trophic ecology, higher resolution can be attained using analyses of other genes (Poulakis et al. 2017). Similar 
to eDNA methods (see Section 2.2.2), some of these techniques require extensive knowledge of the local fauna so samples can be collected to make useful comparisons between better-understood proxy species or across trophic levels (Poulakis et al. 2017). Care should be taken when planning these research projects to ensure realistic timelines and budgets, adequate access to necessary samples, adequate expertise for sample processing, an understanding of any effects of preservation techniques on samples, especially if the study area is remote (Olin et al. 2014), and acquisition of any associated permits (e.g. field sampling, sample shipping).

Other state-of-the-art techniques such as use of time-synchronized acoustic receivers to collect continuous estimates of sawfish positions with accuracies of a few meters and use of accelerometers to link behaviors and physiology to ecology have been initiated on sawfishes (see Section 2.3). These technologies can be used to improve our understanding of habitat use, especially when used simultaneously. For example, knowing where individuals are and what they are doing (e.g. resting, swimming slowly, swimming rapidly) may provide insight on specific habitats being used and when feeding or predator avoidance could be occurring (Whitney et al. 2012).

\subsection{2. $\mathrm{eDNA}$}

Studies of eDNA can build on encounter-derived data (see Section 2.1), or act as a proxy for them in regions where fisheries data are scarce, to foster scientific data collection on sawfishes, especially in remote locations. The relatively new field of eDNA stands to revolutionize our understanding of many species, including sawfishes. Simply put, a water or sediment sample is tested for the presence of DNA from a species of interest. Conceptually, the approach is simple, but practically, many details related to methods must be addressed, well in advance, before any reliable eDNA data can be collected and analyzed. For example, a major requirement for any species-specific eDNA study is development of species-specific primers, or a primer set, that has been thoroughly tested to eliminate the possibility of false positives, such as those from cross-amplification of non-target species (note: biodiversity assessments would use a different approach, see Bakker et al. 2017). False positives are important to avoid so that conservation efforts and research funds are not directed where sawfishes do not exist. Development of a primer set requires extensive knowledge of the local ichthyofauna, especially the most closely related species, which for the purposes of this Theme Section are other sawfishes, guitarfishes, wedgefishes, and stingrays (Last et al. 2016). Primers that work in one study area may not be appropriate for another study area, depending on the related taxa found there, which themselves may have to be sampled for DNA if archived samples are unavailable (e.g. fin clip collections, GenBank records). Problems can arise if the local ichthyofauna is not well known or includes closely related taxa that are rare or are becoming so (Moore 2017 this Theme Section). In addition, obtaining the required state, federal, and international permits can add substantially to the time required to complete the process if samples of protected species such as sawfishes need to be shipped across borders. Permit acquisition and maintenance are sometimes underappreciated aspects of working with protected species because they can take months or years to secure. Even though water or sediment samples for eDNA research may not themselves require permits, necessary supporting work usually does. Collaborations with other researchers can help with local knowledge and permitting-related aspects of research, but the indirect requirements of conducting reliable eDNA research can be expensive and timeconsuming, especially because field and laboratory work is involved. Thus, we recommend that researchers and funding entities consider these factors when developing project timelines and budgets.

Contamination must also be addressed from multiple perspectives (e.g. between samples or from external sources) before eDNA samples can be collected (Goldberg et al. 2016). Because the latest techniques are so sensitive, false positives could result if water samples are collected on a vessel on which a sawfish has been collected or if water samples are filtered in a laboratory in which sawfish parts or tissues have been processed. Simpfendorfer et al. (2016 this Theme Section) conducted the first eDNA study that applied this fast-evolving field to a sawfish species the largetooth sawfish Pristis pristis. They filtered surface water and analyzed samples using conventional PCR techniques. Since that study was published about $3 \mathrm{yr}$ ago, the field of eDNA has moved from using PCR, to quantitative PCR (qPCR), and now into highly sensitive droplet digital (ddPCR) techniques for quantifying results (Baker et al. 2018). The importance of eliminating contamination cannot be overstated, as some ddPCR assays can detect $<1 \mathrm{pg}$ of target DNA (Doi et al. 2015). It is imperative to establish protocols to reduce the risk of contamination, such as cleaning all field and laboratory equip- 
ment with $10 \%$ bleach, ultraviolet light, and autoclaves. Globally, several sawfish eDNA studies are being planned or are underway, and we hope investigators will collaborate as much as possible so that the results of these studies are valid, comparable, and minimize duplication of effort.

Once reliable methods have been established (e.g. vetted species-specific primer set developed, decontamination protocols established) and adequate numbers and volumes of water samples have been collected (to minimize false negatives), eDNA sampling can be used to establish the presence of a target species in a study area and to potentially direct field research. Ideally, these eDNA data would be used as part of multiple lines of evidence used to document the presence of the target species and establishing occupied habitat. For example, eDNA could be used to measure recovery of a sawfish species if encounter reports were received from, or were suspected in, a new area; eDNA sampling becomes the next step in a sawfish-targeted monitoring program. The use of robust eDNA methods could be used for 'early detection' of presence to help researchers and managers foster recovery. Knowing whether these species are present and having estimates of the spatial extent where they occur would inform conservation and management actions. Field surveys and acoustic tagging studies would still be necessary to answer more detailed questions regarding demography, habitat use, site fidelity, and population status, but future improvements in eDNA techniques may provide insight into some of those questions as well. Regardless, we stress the need for careful experimental planning and quality control for any eDNA study, especially if the results might be a primary basis for conservation and management actions.

\subsection{Tagging studies and habitat use}

In general, sawfishes inhabit shallow $(<10 \mathrm{~m})$ coastal waters, including estuaries and rivers of the tropics and subtropics (Dulvy et al. 2016), though they have been shown to occur to about $100 \mathrm{~m}$ depth (Poulakis \& Seitz 2004, Carlson et al. 2014). Encounters with the species from public and research sources have provided insight into habitat use by all life stages. Associations with shallow-water habitats such as mangrove shorelines have been documented, and encounters have most often been reported over muddy or sandy bottoms (Poulakis \& Seitz 2004, Thorburn et al. 2008, Whitty et al. 2009, Wiley \& Simpfendorfer 2010, Morgan et al. 2015, 2017).
For the 2 species that have been studied the most, the smalltooth sawfish and largetooth sawfish, habitat use changes with ontogeny, and smaller animals are found in shallower water and larger animals in deeper water (Poulakis \& Seitz 2004, Whitty et al. 2009, 2017, Simpfendorfer et al. 2010, 2011, Poulakis et al. 2013, Carlson et al. 2014). The smallest juveniles have had the most specific habitat associations in nearshore areas, and these have been targeted relatively easily with recovery efforts (e.g. critical habitat designation, fishery-independent gill-net surveys in shallow water). Larger juveniles and adults, however, have more varied habitat associations (Poulakis \& Seitz 2004, Carlson et al. 2014, Waters et al. 2014). For other species, future research and recovery efforts may need to be more broadly based or targeted at specific areas (e.g. aggregation sites), depending on the goals of those efforts.

Combined with local ecological knowledge and fisheries-independent data, when available, use of long-lasting acoustic tags, especially when placed internally, will likely be the most informative way to improve our understanding of large-scale migrations, smaller-scale localized movements, and habitat use of all life stages. Pop-up satellite archival tags (PSATs) have been used on smalltooth sawfish and have indicated relatively small-scale movements (i.e. within Florida state waters) over $\sim 5$ mo time periods and have provided insight concerning patterns of depth use (Carlson et al. 2014). Thus, in areas where sawfish are rarely encountered and little is known about their habitat use patterns, PSATs are likely the most useful tracking method. However, given cost-benefit considerations and light-based location error estimates of PSATs, acoustic transmitters and subsequent monitoring by acoustic receivers may be a better investment for sawfishes, provided the infrastructure is available for deployment and long-term maintenance of receiver arrays of ecologically meaningful size. Smart position and temperature (SPOT) tags (satellite tags that provide real-time locations when they break the surface) have shown some promise, but are useful only for sawfish using shallow habitats over relatively short time periods (i.e. months, R. D. Grubbs unpubl. data). Some studies have already provided much-needed, longer-term information on sawfishes using internal acoustic tags (Whitty et al. 2017), but permit requirements and cautious approaches to conducting research on these threatened species have resulted in the use of external tags until relatively recently. As a result, most studies have focused on habitat use by small juveniles because of their high site fidelity (e.g. Whitty et 
al. 2009, Poulakis et al. 2013, Morgan et al. 2015, 2017, Scharer et al. 2017). The short retention times of externally attached tags limit their utility in understanding the ecology of long-lived species such as sawfishes. The expanded use of internally placed acoustic tags, especially appealing now that recaptures have shown that the incisions made for implantation heal completely, are proving instrumental for filling data gaps within and beyond the nurseries (Whitty et al. 2017, R. D. Grubbs \& G. R. Poulakis unpubl. data). With battery lives up to $10 \mathrm{yr}$, internally implanted acoustic tags may provide information about movements and habitat use over large portions of the lives of these long-lived species.

Sawfishes spend their first few years within nurseries and eventually move into a broader range of coastal habitats. Use of acoustic tags has improved our understanding of the early life history of 3 species: the smalltooth sawfish, largetooth sawfish, and green sawfish Pristis zijsron. General movement patterns (e.g. on the scale of an entire river) have been documented with regular acoustic tags and receivers, but use of time-synchronized acoustic receivers to continuously estimate sawfish positions within meters (G. R. Poulakis \& R. A. May unpubl. data) and use of accelerometers to link behaviors and physiology to ecology (Gleiss et al. 2017, N. M. Whitney, K. O. Lear, \& G. R. Poulakis unpubl. data) have been conducted or initiated on sawfishes, and these technologies have great potential to improve our understanding of finer-scale habitat use, especially within the nurseries. For example, accelerometers have documented seasonal patterns of depth use by the largetooth sawfish and diel patterns of activity by the smalltooth sawfish (Gleiss et al. 2017). Some of these approaches may be useful outside the nurseries, such as in adult aggregation sites, but because of high site fidelity, relatively small activity spaces, and hotspot use within the broader nurseries (e.g. Poulakis et al. 2011, 2013, 2016, Morgan et al. 2015, 2017, Nagelkerken et al. 2015, Hollensead et al. 2016), data collection has been maximized and, in the case of accelerometers, tag recovery has been optimized in nursery habitats.

Improving our understanding of ontogenetic shifts in habitat use after age- 0 , such as critical habitats for large juveniles and adults, as well as associations of adult females with specific nurseries, will need to be a focus of future research for all sawfish species. Progress has been made in this regard for some species, such as the smalltooth sawfish and narrow sawfish Anoxypristis cuspidata, but gaps remain. For example, Feldheim et al. (2017) reconstructed adult female genotypes from DNA collected from young smalltooth sawfish captured in 2 of at least 5 unique nurseries (Norton et al. 2012), and showed strong, decade-scale, biennial parturition site fidelity, which is often a precursor to establishing maternal natal philopatry (Chapman et al. 2015). Similarly, Green et al. (2018) examined larger-scale population structure of the narrow sawfish and found evidence of regional parturition site fidelity. Using these or similar approaches to study the relationship between the migrations of adult females and their nurseries range-wide for all sawfishes where long time series of DNA samples exist will improve our understanding of their life histories and may help prioritize conservation and management actions.

Like for many marine species, temperature has emerged as a driver of habitat use on a variety of temporal and spatial scales for some sawfishes. For example, during normal daily or seasonal fluctuations, small-scale movements of juvenile largetooth sawfish and all life stages of the smalltooth sawfish have been influenced by temperature (Papastamatiou et al. 2015, Gleiss et al. 2017, Whitty et al. 2017). These studies have shown that the timing of shifts in habitat use, such as moving from the shallows to deeper water (or vice versa) in the same river or moving from canals into the open waters of an embayment, may be cued by temperature. In addition, atypical cold events have been shown to influence smalltooth sawfish habitat use in nurseries as juveniles look for refuge before succumbing in cases where their lower temperature tolerance limit was exceeded (Poulakis et al. 2011, Scharer et al. 2017). Learning more about species-specific tolerances and how temperature influences habitat use will be important as we continue to assess ranges and project how they might change on a variety of temporal scales related to climate change.

\subsection{Anthropogenic threats and mitigation}

Historically, anthropogenic threats to sawfishes have included targeted catch and bycatch in myriad fisheries (biggest threat), habitat loss and degradation (e.g. destruction of mangrove shorelines), commercial trade in sawfish parts (e.g. highly valued rostra and fins), and entanglement in marine debris (Seitz \& Poulakis 2006, Dulvy et al. 2016, Brame et al. 2019 this Theme Section). These threats have reduced species ranges and caused sawfishes to be eliminated from more than $20 \%$, and perhaps even up to $50 \%$, of the countries in whose waters they 
once existed (Dulvy et al. 2016, Fordham et al. 2018). Due to a variety of conservation actions (e.g. all sawfish species are listed in Appendix I of the Convention on International Trade in Endangered Species of Wild Fauna and Flora [CITES], so international trade should not occur), threats such as legal harvest and trade in live animals have been theoretically eliminated from $24 \%$ of countries in their collective ranges (Fordham et al. 2018). However, implementation of conservation actions, especially their enforcement (Hossain et al. 2015), and fostering of fisher behavioral changes (Battista et al. 2018), and ongoing threats such as fisheries bycatch and habitat loss remain problematic for these species. Establishing effective, ongoing, public outreach and education programs that are catered to the needs of local people (e.g. promoting a shift to ecosystem management, see Section 2.4.1) will be imperative if we hope to mitigate the effects of these threats.

\subsubsection{Fisheries catch and bycatch}

Mortality resulting from artisanal, commercial, and recreational fisheries, intentional or not, has been the primary cause of sawfish population declines worldwide (Seitz \& Poulakis 2006, Dulvy et al. 2016, Brame et al. 2019). The extended, toothed rostrum of sawfishes makes them vulnerable to capture in net fisheries, especially gill nets and trawls, and efforts such as shark control programs that use similar nets. Capture of sawfishes in such efforts has been well documented (e.g. Hossain et al. 2015, Dulvy et al. 2016, Wueringer 2017 this Theme Section). Gill-net fisheries have been eliminated in some portions of the smalltooth sawfish range, such as most US states, including Florida, but more reductions are needed. For example, high-density artisanal gill-net fisheries (e.g. Senegal has over 90000 fishers and 12000 canoes along a $700 \mathrm{~km}$ coastline) in the western Indian and eastern Atlantic oceans still exist off Africa and Bangladesh (Pinnegar \& Engelhard 2008, Hossain et al. 2015). Similarly, in some regions such as India and the USA, trawl fisheries remain a concern, as interactions with them generally result in the death of larger individuals; however, some progress has been made, as trawl fisheries have been banned in waters off the UAE, and there are seasonal closures in other countries such as Kuwait and Bahrain (Brame et al. 2019, R. Jabado pers. comm.).

Sawfish conservation in low-income countries is especially complex because it involves issues of poverty and human welfare in marginalized commu- nities. In these situations, assuming there is a willingness on the part of all involved (i.e. the public, scientists, and management) to make changes and the capacity exists for these changes, one realistic way forward could involve identifying nurseries, migration corridors, and large juvenile and adult critical habitats which would provide guidance in establishing additional time-area closures to minimize interactions with sawfishes and related overfished species, while supporting the original fisheries. As the species become better understood, areas of consistent, intense use may emerge and these may help prioritize spatial and temporal aspects of conservation actions, as has occurred for the smalltooth sawfish (see Section 2.1). Some of these changes may not be very disruptive to the overall fisheries because the same gear could be used (e.g. avoiding $\sim 2 \mathrm{~km}$ portions of a river) and may be easier to implement compared to establishment of large protected areas that tend to be focused on biodiversity (Devitt et al. 2015). Another more expensive possibility that may be an option in some communities could involve integrating hooked gears like modestly sized longlines or drumlines into the fishery, as capture using these techniques likely results in limited physiological stress compared to capture in trawls and gill nets, because large sawfish caught in bottom longline fisheries in the USA are typically released alive (Prohaska et al. 2018, R. D. Grubbs \& G. R. Poulakis unpubl. data).

In the USA and Australia, sawfishes continue to be captured in recreational fisheries, sometimes in large numbers, though the risk of mortality is likely low when they are handled and released properly (Peverell 2005, Waters et al. 2014, Prohaska et al. 2018). Unfortunately, reports of sawfish being retained or released after the removal of their rostra are still received, even in regions with adequate protections and extensive outreach efforts (Seitz \& Poulakis 2006, Morgan et al. 2016). These reports highlight the ongoing need for outreach wherever sawfishes are found, so that coastal residents from all user groups that might encounter sawfish will be aware of the laws and can appreciate the multiplicative value (e.g. through ecotourism and ecosystem management) of live sawfishes as part of healthy ecosystems.

\subsubsection{Habitat loss}

Because sawfishes are found in coastal habitats at all life stages, habitat loss has been and will continue to be a threat, because humans tend to live along the 
coast. Remote regions and large parks have acted as 'life boats' for sawfishes in some parts of the world (e.g. Everglades National Park, Florida; West Side National Park, Andros Island, Bahamas; northern Australia; Papua New Guinea), but in highly developed portions of southwest Florida such as the Charlotte Harbor estuarine system, which contains 2 distinct smalltooth sawfish nurseries (Feldheim et al. 2017, Scharer et al. 2017), many mangrove-lined shorelines have been replaced by concrete seawalls or other armored shorelines to protect waterfront property (Poulakis et al. 2011, 2013, 2016, Norton et al. 2012, Scharer et al. 2017). Although the species is physiologically resilient, Prohaska et al. (2018) showed that juvenile smalltooth sawfish in Charlotte Harbor nurseries had higher metabolic stress than juveniles from more pristine nurseries. These results suggest that living in human-altered or fragmented habitats may cause chronic stress in juveniles, though any effects on body condition, behavior, or survival are unknown.

Mangroves have been demonstrated to serve as important foundation habitats supporting most, if not all, sawfishes and their ecosystems, yet mangrove deforestation due to urban development, aquaculture, agriculture, tourism, and lumber acquisition continues to result in global loss of this habitat (Duke et al. 2007, Friess \& Webb 2014). The effects of mangrove loss in countries that remain strongholds for 1 or more species (e.g. Papua New Guinea, Australia, USA), or those where recent data suggest that viable populations may still exist (e.g. Sundarbans region of Bangladesh, India [R. Jabado pers. comm.], Pakistan, Cuba, Bahamas), could be a major impediment to recovery. It is encouraging, however, that research results have been, and will continue to be, used to influence habitat-modification projects to avoid and minimize loss of mangroves and other habitats in both units of official juvenile smalltooth sawfish critical habitat in Florida (Norton et al. 2012, NMFS pers. comm.). Hopefully, emerging research results in other parts of the world can be used to safeguard habitats similarly, even on small spatial scales (see Section 2.4.1), and a message of how these actions benefit the entire ecosystem, not just sawfishes, can be disseminated to affected parties as part of the process.

\subsubsection{Marine debris and other threats}

Although currently a relatively minor threat, especially compared to fishing catch and bycatch (see Section 2.4.1), marine debris is an ongoing threat to sawfishes, especially juveniles, whose elongate, toothed rostra are easily entangled or encircled. This threat could be more important than currently thought if affected sawfish are trapped at depth (e.g. in discarded monofilament longline, G. R. Poulakis unpubl. data) or in the future if populations begin to recover, which would increase the chances of interactions and counteract recovery progress. For sawfishes, marine debris includes a range of humanmade materials that are found wherever sawfishes are found, including monofilament fishing line of all strengths, non-monofilament line, and other refuse, especially if it is or can become cylindrical (Seitz \& Poulakis 2006). A wide range of cylindrical objects have been found on rostra and heads of sawfishes because their rostra pass through the center of the object, and the object either gets stuck on the rostral teeth or passes beyond the rostrum and stops at the broader head. Objects that have been found on sawfish include loops of various types of rope (e.g. from commercial traps), a section of polyvinyl chloride (PVC) pipe, loops of monofilament fishing line, a dog's plastic ball, and rubber bands (Seitz \& Poulakis 2006, G. R. Poulakis unpubl. data).

The severity of debris-related injuries and their effects on individual fitness varies. Objects that have been on sawfish for a long time-months or even years - have caused serious injuries or healed such that the objects have become incorporated into the body (Seitz \& Poulakis 2006). Rostral damage has included broken or lost rostral teeth and damage to the rostral cartilage. These injuries can have lasting effects because lost rostral teeth do not regrow (Slaughter \& Springer 1968), and damaged cartilage can result in weakening or breaking of the rostrum. Monofilament lines do not have to be wrapped tightly around the rostrum to cause damage because of the normal lateral slashing behavior sawfishes employ for feeding and defense. In recent years, rubber bands have become a relatively common occurrence on juvenile smalltooth sawfish, especially in the Caloosahatchee River, Florida (G. R. Poulakis pers. obs.). Apparently, the estuarine salinities in this nursery preserve the rubber's elasticity, causing open wounds in multiple individuals, and impeding spiracle function in one instance. Incorporating these threats into outreach presentations and encouraging fishers to untangle unintentionally caught sawfishes as much as possible before release is recommended and will help lessen these effects.

Natural threats such as disease, parasites, and stochastic events (e.g. extreme cold weather events, hurricanes, algal blooms) to sawfishes are largely 
unknown, but they clearly stand to impede recovery. In Australia and the Bahamas, juvenile sawfishes sometimes get trapped on drying floodplains or sand flats and need to be rescued by researchers or indigenous rangers (R. D. Grubbs \& P. M. Kyne unpubl. data.). Making local people aware of the weather conditions (e.g. onset of dry season, shortterm blowdown events) that increase the possibility of this happening may prevent mortality events. Some natural threats might be related and provide early warnings of future problems. For example, parasites are part of healthy ecosystems, but excessive ecto- or endoparasite loads could indicate compromised health of an individual or group, or disruptions in the overall health of the ecosystem. Identifying metazoan parasites that affect sawfishes, especially since many are infection site- and host-specific, and establishing baseline infection rates, may help determine indicator species that could assess the severity of future imbalances in the ecosystem (Kritsky et al. 2017, Bakenhaster et al. 2018).

In general, sawfishes seem to be a resilient group (Prohaska et al. 2018), but monitoring the effects of these threats, especially if they occur near occupied habitats, is recommended. In addition, promoting sample collection, especially when mortalities occur, will maximize the knowledge gained from these unfortunate events (see Sections 2.2.1 and 2.3).

\subsection{Related species}

Globally, sawfishes have received considerable research and conservation attention in recent years because they are among the elasmobranch taxa most at risk of extinction (Dulvy et al. 2014, 2016). Yet many other species with similar life-history traits are just as susceptible to overfishing and could be in the same situation as sawfishes now or soon. Wedgefishes and guitarfishes (especially the Rhinidae and Glaucostegidae), for example, are vulnerable groups that are closely related to sawfishes in the Order Rhinopristiformes and inhabit similar habitats as sawfishes (Last et al. 2016, Moore 2017). We recommend incorporating these taxa into sawfish-focused conservation and outreach efforts and promoting healthy ecosystems while maximizing biodiversity. In addition, understanding the biology, ecology, and status of these related species may be critical in informing research on sawfishes, such as studies on trophic ecology (see Section 2.2.1) and development of species-specific primers for eDNA research (see Section 2.2.2).

\section{CONCLUSIONS}

It is our hope that this Theme Section will serve as a resource for research ideas and aid in informing responses to conservation and management issues that arise for sawfishes and related taxa worldwide. In addition, we encourage researchers to collaborate as much as possible on research projects. The benefits of collaborative science are not unique to studies of sawfishes, but this group of threatened fishes will have the best chance for survival if researchers work together and make decisions with the species as the priority. As a field-based example, funding for acoustic tags and receivers can sometimes be scarce when needed for many reasons, but sharing tags and unused receivers between researchers (i.e. items that have already been purchased and can be mobilized quickly) may allow researchers to take advantage of time-sensitive tagging and data collection opportunities. Further, participating in existing acoustic detection sharing networks, or developing new ones, will be instrumental in advancing our understanding of sawfishes, as the benefits of this approach have been realized for many large, mobile species, including the smalltooth sawfish (e.g. Hussey et al. 2015, Pratt et al. 2018, Ellis et al. 2019). In the laboratory, communicating about successes and failures regarding sampling protocols and species-specific primer development, well in advance of scheduled eDNA sampling, will reduce costs and maximize efficiency, while minimizing delays. Streamlining research as much as possible will maximize recovery benefits because these species need our collective help as soon as possible.

Ultimately, effective and timely translation of the results of scientific research into conservation and management actions that include enforcement and efforts to change fisher behavior will be important in the future, especially in countries outside the USA and Australia. Ongoing local ecological knowledge reports highlight the ongoing need for outreach and behavior change efforts wherever sawfishes are found, so that coastal residents from all user groups that might encounter sawfishes will be aware of existing laws and can appreciate the multiplicative value of live sawfishes as part of healthy ecosystems (e.g. Battista et al. 2018). Successful conservation is certainly a complicated issue, especially in impoverished coastal communities in low-income countries. Effective management and conservation will require addressing socioeconomic issues that lead to overfishing. Solutions must include human behavior change, development and promotion of alternative 
livelihoods, and food security through sources of sustainable protein, exclusion of industrial fishing fleets, and approaches such as theory of change (e.g. Mayne 2015). If an appreciation of healthy ecosystems that contain top predators like sawfishes can be fostered by healthy human populations where sawfishes occur, and local knowledge can be used to inform scientific studies that subsequently inform customized management decisions, this group of iconic species will have a chance to recover.

Acknowledgements. Most of the work published as part of this Theme Section was presented as part of the symposium 'Biology and ecology of sawfishes', held at the 2016 annual meeting of the American Elasmobranch Society. Major funding for this symposium was through a Keystone Grant from the Save Our Seas Foundation with additional support from the Disney Conservation Fund and the American Elasmobranch Society. Attendance at the symposium, especially by researchers working in developing countries, would not have been possible without funding support from the Save Our Seas Foundation and the Disney Conservation Fund. We thank all participants who attended the symposium and all authors who submitted manuscripts for the Theme Section. Thanks to all reviewers for maximizing the impact of each manuscript. We are grateful to Brendan Godley, editorin-chief, for his enthusiastic support of the Theme Section since its inception. Adam Brame, Bland Crowder, Brendan Godley, Rima Jabado, Ed Matheson, Nicole Phillips, Rachel Scharer, Jeff Whitty, and 3 anonymous reviewers improved earlier versions of the Overview.

\section{LITERATURE CITED}

Bakenhaster MD, Bullard SA, Curran SS, Kritsky DC and others (2018) Parasite component community of smalltooth sawfish off Florida: diversity, conservation concerns, and research applications. Endang Species Res 35: 47-58

Baker CS, Steel D, Nieukirk S, Klinck H (2018) Environmental DNA (eDNA) from the wake of whales: droplet digital PCR for detection and species identification. Front Mar Sci 5:133

Bakker J, Wangensteen OS, Chapman DD, Boussarie G and others (2017) Environmental DNA reveals tropical shark diversity in contrasting levels of anthropogenic impact. Sci Rep 7:16886

Battista W, Romero-Canyas R, Smith SL, Fraire J, Effron M, Larson-Konar D, Fujita R (2018) Behavior change interventions to reduce illegal fishing. Front Mar Sci 5:403

Bonfil R, Mendoza-Vargas OU, Ricaño-Soriano M, PalaciosBarreto PY, Bolaño-Martínez N (2017) Former widespread abundance and recent downfall of sawfishes in Mexico as evidenced by historical photographic and trophy records. Fisheries (Bethesda, Md) 42:256-259

Bonfil R, Ricaño-Soriano M, Mendoza-Vargas OU, MéndezLoeza I, Pérez-Jiménez JC, Bolaño-Martínez N, PalaciosBarreto P (2018) Tapping into local ecological knowledge to assess the former importance and current status of sawfishes in Mexico. Endang Species Res 36:213-228
Brame AB, Wiley TR, Carlson JK, Fordham SV and others (2019) Biology, ecology, and status of the smalltooth sawfish Pristis pectinata in the USA. Endang Species Res 39: 9-23

* Carlson J, Wiley T, Smith K (2013) Pristis pectinata (errata version published in 2019). The IUCN Red List of Threatened Species 2013: e.T18175A141791261. http://dx.doi. org/10.2305/IUCN.UK.2013-1.RLTS.T18175A141791261. en (accessed 6 June 2019)

* Carlson JK, Gulak SJB, Simpfendorfer CA, Grubbs RD, Romine JG, Burgess GH (2014) Movement patterns and habitat use of smalltooth sawfish, Pristis pectinata, determined using pop-up satellite archival tags. Aquat Conserv 24:104-117

* Chapman DD, Simpfendorfer CA, Wiley TR, Poulakis GR and others (2011) Genetic diversity despite population collapse in a critically endangered marine fish: the smalltooth sawfish (Pristis pectinata). J Hered 102:643-652

Chapman DD, Feldheim KA, Papastamatiou YP, Hueter RE (2015) There and back again: a review of residency and return migrations in sharks, with implications for population structure and management. Annu Rev Mar Sci 7: $547-570$

* Cuevas JM, García M, Hozbor N, Faria VV, Paesch L (2019) Tracing the occurrence of the Critically Endangered smalltooth sawfish Pristis pectinata at its southernmost distribution in the Southwest Atlantic Ocean. Endang Species Res 38:1-9

* Devitt KR, Adams VM, Kyne PM (2015) Australia's protected area network fails to adequately protect the world's most threatened marine fishes. Glob Ecol Conserv 3:401-411

* DiBattista JD, Feldheim KA, Thibert-Plante X, Gruber SH, Hendry AP (2008) A genetic assessment of polyandry and breeding-site fidelity in lemon sharks. Mol Ecol 17: 3337-3351

* Doi H, Takahara T, Minamoto T, Matsuhashi S, Uchii K, Yamanaka H (2015) Droplet digital polymerase chain reaction (PCR) outperforms real-time PCR in the detection of environmental DNA from an invasive fish species. Environ Sci Technol 49:5601-5608

* Duke NC, Meynecke JO, Dittmann S, Ellison AM and others (2007) A world without mangroves? Science 317:41-42

* Dulvy NK, Fowler SL, Musick JA, Cavanagh RD and others (2014) Extinction risk and conservation of the world's sharks and rays. eLife 3:e00590

* Dulvy NK, Davidson LNK, Kyne PM, Simpfendorfer CA, Harrison LR, Carlson JK, Fordham SV (2016) Ghosts of the coast: global extinction risk and conservation of sawfishes. Aquat Conserv 26:134-153

Elhassan IS (2018) Occurrence of the green sawfish Pristis zijsron in the Sudanese Red Sea with observations on reproduction. Endang Species Res 36:41-47

*Ellis RD, Flaherty-Walia KE, Collins AB, Bickford JW, Boucek R, Walters-Burnsed SL, Lowerre-Barbieri SK (2019) Acoustic telemetry array evolution: from speciesand project-specific designs to large-scale, multispecies, cooperative networks. Fish Res 209:186-195

Faria VV, McDavitt MT, Charvet P, Wiley TR, Simpfendorfer CA, Naylor GJP (2013) Species delineation and global population structure of critically endangered sawfishes (Pristidae). Zool J Linn Soc 167:136-164

Feldheim KA, Gruber SH, Ashley MV (2004) Reconstruction of parental microsatellite genotypes reveals female polyandry and philopatry in the lemon shark, Negaprion 
brevirostris. Evolution 58:2332-2342

Feldheim KA, Fields AT, Chapman DD, Scharer RM, Poulakis GR (2017) Insights into reproduction and behavior of the smalltooth sawfish Pristis pectinata. Endang Species Res 34:463-471

Fordham SV, Jabado R, Kyne PM, Charvet P, Dulvy NK (2018) Saving sawfish: progress and priorities. IUCN Shark Specialist Group, Vancouver

Friess DA, Webb EL (2014) Variability in mangrove change estimates and implications for the assessment of ecosystem service provision. Glob Ecol Biogeogr 23:715-725

FWC (Florida Fish and Wildlife Conservation Commission) (1999) Protected species: sawfishes, basking shark, whale shark, white shark, sand tiger shark, bigeye sand tiger shark, manta ray, and spotted eagle ray; prohibition of harvest, landing, and sale. Chapter 68B-44.008 (formerly 46-44.008). Florida Administrative Code Rule 11: 1222

Gleiss AC, Morgan DL, Whitty JM, Keleher JJ, Fossette S, Hays GC (2017) Are vertical migrations driven by circadian behaviour? Decoupling of activity and depth use in a large riverine elasmobranch, the freshwater sawfish (Pristis pristis). Hydrobiologia 787:181-191

Goldberg CS, Turner CR, Deiner K, Klymus KE and others (2016) Critical considerations for the application of environmental DNA methods to detect aquatic species. Methods Ecol Evol 7:1299-1307

* Green ME, D'Anastasi BR, Hobbs JPA, Feldheim K and others (2018) Mixed-marker approach suggests maternal philopatry and sex-biased behaviours of narrow sawfish Anoxypristis cuspidata. Endang Species Res 37:45-54

Harrison LR, Dulvy NK (2014) Sawfish: a global strategy for conservation. IUCN Species Survival Commission's Shark Specialist Group, Vancouver

Heupel MR, Carlson JK, Simpfendorfer CA (2007) Shark nursery areas: concepts, definition, characterization and assumptions. Mar Ecol Prog Ser 337:287-297

*Heupel MR, Kanno S, Martins APB, Simpfendorfer CA (2018) Advances in understanding the roles and benefits of nursery areas for elasmobranch populations. Mar Freshw Res, doi:10.1071/MF18081

Hollensead LD, Grubbs RD, Carlson JK, Bethea DM (2016) Analysis of fine-scale daily movement patterns of juvenile Pristis pectinata within a nursery habitat. Aquat Conserv 26:492-505

Hollensead LD, Grubbs RD, Carlson JK, Bethea DM (2018) Assessing residency time and habitat use of juvenile smalltooth sawfish using acoustic monitoring in a nursery habitat. Endang Species Res 37:119-131

Hossain MA, Thompson BS, Chowdhury GW, Mohsanin S, Fahad ZH, Koldewey HJ, Islam MA (2015) Sawfish exploitation and status in Bangladesh. Aquat Conserv 25:781-799

*Hussey NE, Kessel ST, Aarestrup K, Cooke SJ and others (2015) Aquatic animal telemetry: a panoramic window into the underwater world. Science 348:1255642

Huston CA, Stevens PW, Blaxton RM, Tolley SG, Scharer RM, Tornwall BM, Poulakis GR (2017) Diel movements of juvenile smalltooth sawfish: implications for defining the size of a nursery hotspot. Endang Species Res 34: 311-322

IUCN (International Union for the Conservation of Nature) (1996) 1996 IUCN Red List of Threatened Animals. IUCN, Gland
Jabado RW, Al Baharna RA, Al Ali SR, Al Suwaidi KO, Al Blooshi AY, Al Dhaheri SS (2017) Is this the last stand of the Critically Endangered green sawfish Pristis zijsron in the Arabian Gulf? Endang Species Res 32:265-275

Kritsky DC, Bullard SA, Bakenhaster MD, Scharer RM, Poulakis GR (2017) Resurrection of Mycteronastes (Monogenoidea: Monocotylidae), with description of Mycteronastes caalusi n. sp. from olfactory sacs of the smalltooth sawfish, Pristis pectinata (Pristiformes: Pristidae) in the Gulf of Mexico off Florida. J Parasitol 103: 477-485

KKyne PM, Carlson J, Smith K (2013) Pristis pristis (errata version published in 2019). The IUCN Red List of Threatened Species 2013: e.T18584848A141788242. http://dx. doi.org/10.2305/IUCN.UK.2013-1.RLTS.T18584848A141 788242.en (accessed 6 June 2019)

Last PR, Stevens JD (2009) Sharks and rays of Australia. Harvard University Press, Cambridge, MA

Last PR, White WT, de Carvalho MR, Séret B, Stehmann MFW, Naylor GJP (2016) Rays of the world. Cornell University Press, Ithaca, NY

* Leeney RH, Downing N (2016) Sawfishes in The Gambia and Senegal-shifting baselines over 40 years. Aquat Conserv 26:265-278

*Leeney RH, Mana RR, Dulvy NK (2018) Fishers' ecological knowledge of sawfishes in the Sepik and Ramu rivers, northern Papua New Guinea. Endang Species Res 36: $15-26$

Manir Feitosa L, Barbosa Martins AP, Silva Nunes JL (2017) Sawfish (Pristidae) records along the Eastern Amazon coast. Endang Species Res 34:229-234

*Mayne J (2015) Useful theory of change models. Can J Prog Eval 30:119-142

*Moore ABM (2017) Are guitarfishes the next sawfishes? Extinction risk and an urgent call for conservation action. Endang Species Res 34:75-88

* Morgan DL, Allen MG, Ebner BC, Whitty JM, Beatty SJ (2015) Discovery of a pupping site and nursery for critically endangered green sawfish (Pristis zijsron). J Fish Biol 86:1658-1663

Morgan DL, Wueringer BE, Allen MG, Ebner BC and others (2016) What is the fate of amputee sawfish? Fisheries 41:71-73

* Morgan DL, Ebner BC, Allen MG, Gleiss AC, Beatty SJ, Whitty JM (2017) Habitat use and site fidelity of neonate and juvenile green sawfish Pristis zijsron in a nursery area in Western Australia. Endang Species Res 34: 235-249

Nagelkerken I, Sheaves M, Baker R, Connolly RM (2015) The seascape nursery: a novel spatial approach to identify and manage nurseries for coastal marine fauna. Fish Fish 16:362-371

NMFS (US National Marine Fisheries Service) (2003) Endangered and threatened species; final endangered status of a distinct population segment of smalltooth sawfish (Pristis pectinata) in the United States. Fed Regist 68: 15674-15680

NMFS (2009) Recovery plan for smalltooth sawfish (Pristis pectinata). Prepared by the Smalltooth Sawfish Recovery Team for the NMFS, Silver Spring, MD

Norton SL, Wiley TR, Carlson JK, Frick AL, Poulakis GR, Simpfendorfer CA (2012) Designating critical habitat for juvenile endangered smalltooth sawfish in the United States. Mar Coast Fish 4:473-480

* Olin JA, Poulakis GR, Stevens PW, DeAngelo JA, Fisk AT 
(2014) Preservation effects on stable isotope values of archived elasmobranch fin tissue: comparisons between frozen and ethanol-stored samples. Trans Am Fish Soc 143:1569-1576

Papastamatiou YP, Grubbs RD, Imhoff JL, Gulak SJB, Carlson JK, Burgess GH (2015) A subtropical embayment serves as essential habitat for sub-adults and adults of the critically endangered smalltooth sawfish. Glob Ecol Conserv 3:764-775

Peverell SC (2005) Distribution of sawfishes (Pristidae) in the Queensland Gulf of Carpentaria, Australia, with notes on sawfish ecology. Environ Biol Fishes 73:391-402

Phillips NM, Chaplin J, Morgan D, Peverell S (2009) Extraction and amplification of DNA from the dried rostra of sawfishes (Pristidae) for applications in conservation genetics. Pac Conserv Biol 15:128-134

Fhillips NM, Fearing A, Morgan DL (2017) Genetic bottlenecks in Pristis sawfishes in northern Australian waters. Endang Species Res 32:363-372

Pinnegar JK, Engelhard GH (2008) The 'shifting baseline' phenomenon: a global perspective. Rev Fish Biol Fish 18: $1-16$

Poulakis GR, Seitz JC (2004) Recent occurrence of the smalltooth sawfish, Pristis pectinata (Elasmobranchiomorphi: Pristidae), in Florida Bay and the Florida Keys, with comments on sawfish ecology. Fla Sci 67:27-35

* Poulakis GR, Stevens PW, Timmers AA, Wiley TR, Simpfendorfer CA (2011) Abiotic affinities and spatiotemporal distribution of the endangered smalltooth sawfish, Pristis pectinata, in a south-western Florida nursery. Mar Freshw Res 62:1165-1177

* Poulakis GR, Stevens PW, Timmers AA, Stafford CJ, Simpfendorfer CA (2013) Movements of juvenile endangered smalltooth sawfish, Pristis pectinata, in an estuarine river system: use of non-main-stem river habitats and lagged responses to freshwater inflow-related changes. Environ Biol Fishes 96:763-778

Poulakis GR, Stevens PW, Timmers AA, Stafford CJ and others (2016) Long-term site fidelity of endangered smalltooth sawfish (Pristis pectinata) from different mothers. Fish Bull 114:461-475

* Poulakis GR, Urakawa H, Stevens PW, DeAngelo JA and others (2017) Sympatric elasmobranchs and fecal samples provide insight into the trophic ecology of the smalltooth sawfish. Endang Species Res 32:491-506

Pratt HL Jr, Pratt TC, Morley D, Lowerre-Barbieri S and others (2018) Partial migration of the nurse shark, Ginglymostoma cirratum (Bonnaterre), from the Dry Tortugas Islands. Environ Biol Fishes 101:515-530

* Prohaska BK, Bethea DM, Poulakis GR, Scharer RM, Knotek R, Carlson JK, Grubbs RD (2018) Physiological stress in the smalltooth sawfish: effects of ontogeny, capture method, and habitat quality. Endang Species Res 36: 121-135

* Reis-Filho JA, Freitas RHA, Loiola M, Leite L and others (2016) Traditional fisher perceptions on the regional disappearance of the largetooth sawfish Pristis pristis from the central coast of Brazil. Endang Species Res 29: $189-200$

* Sáenz-Arroyo A, Roberts CM, Torre J, Cariño-Olvera M (2005) Using fishers' anecdotes, naturalists' observations and grey literature to reassess marine species at risk: the case of the Gulf grouper in the Gulf of California, Mexico. Fish Fish 6:121-133

* Scharer RM, Patterson WF III, Carlson JK, Poulakis GR
(2012) Age and growth of endangered smalltooth sawfish (Pristis pectinata) verified with LA-ICP-MS analysis of vertebrae. PLOS ONE 7:e47850

* Scharer RM, Stevens PW, Shea CP, Poulakis GR (2017) All nurseries are not created equal: large-scale habitat use patterns in two smalltooth sawfish nurseries. Endang Species Res 34:473-492

Seitz JC, Hoover JJ (2017) Taxonomic resolution of sawfish rostra from two private collections. Endang Species Res 32:525-532

Seitz JC, Poulakis GR (2002) Recent occurrence of sawfishes (Elasmobranchiomorphi: Pristidae) along the southwest coast of Florida (USA). Fla Sci 65:256-266

Seitz JC, Poulakis GR (2006) Anthropogenic effects on the smalltooth sawfish (Pristis pectinata) in the United States. Mar Pollut Bull 52:1533-1540

Simpfendorfer C (2013) Pristis zijsron (errata version published in 2019). The IUCN Red List of Threatened Species 2013: e.T39393A141792003. http://dx.doi.org/ 10.2305/IUCN.UK.2013-1.RLTS.T39393A141792003.en (accessed 6 June 2019)

พ Simpfendorfer CA, Wiley TR, Yeiser BG (2010) Improving conservation planning for an endangered sawfish using data from acoustic telemetry. Biol Conserv 143: 1460-1469

Simpfendorfer CA, Yeiser BG, Wiley TR, Poulakis GR, Stevens PW, Heupel MR (2011) Environmental influences on the spatial ecology of juvenile smalltooth sawfish (Pristis pectinata): results from acoustic monitoring. PLOS ONE 6:e16918

Simpfendorfer CA, Kyne PM, Noble TH, Goldsbury J and others (2016) Environmental DNA detects Critically Endangered largetooth sawfish in the wild. Endang Species Res 30:109-116

Slaughter BH, Springer S (1968) Replacement of rostral teeth in sawfishes and sawsharks. Copeia 1968: 499-506

* Thorburn DC, Morgan DL, Rowland AJ, Gill HS, Paling E (2008) Life history notes of the Critically Endangered dwarf sawfish, Pristis clavata, Garman 1906 from the Kimberley region of Western Australia. Environ Biol Fishes 83:139-145

Thorburn DC, Gill HS, Morgan DL (2014) Predator and prey interactions of fishes of a tropical Western Australia river revealed by dietary and stable isotope analyses. J R Soc West Aust 97:363-387

Thorson TB (1976) Observations on the reproduction of the sawfish, Pristis perotteti, in Lake Nicaragua, with recommendations for its conservation. In: Thorson TB (ed) Investigations of the ichthyofauna of Nicaraguan lakes. University of Nebraska-Lincoln, Lincoln, NE, p 641-650

* Thorson TB (1982a) Life history implications of a tagging study of the largetooth sawfish, Pristis perotteti, in the Lake Nicaragua-Río San Juan system. Environ Biol Fishes 7:207-228

* Thorson TB (1982b) The impact of commercial exploitation on sawfish and shark populations in Lake Nicaragua. Fisheries (Bethesda, MD) 7:2-10

* Waters JD, Coelho R, Fernandez-Carvalho J, Timmers AA and others (2014) Use of encounter data to model spatiotemporal distribution patterns of endangered smalltooth sawfish, Pristis pectinata, in the western Atlantic. Aquat Conserv 24:760-776

*White WT, Appleyard SA, Kyne PM, Mana RR (2017) Sawfishes in Papua New Guinea: a preliminary investigation 
into their status and level of exploitation. Endang Species Res 32:277-291

Whitney NM, Papastamatiou YP, Gleiss AC (2012) Integrative multisensor tagging: emerging techniques to link elasmobranch behavior, physiology, and ecology. In: Carrier JC, Musick JA, Heithaus MR (eds) Biology of sharks and their relatives. CRC Press, Boca Raton, FL, p 265-290

Whitty JM, Morgan DL, Peverell SC, Thorburn DC, Beatty SJ (2009) Ontogenetic depth partitioning by juvenile freshwater sawfish (Pristis microdon: Pristidae) in a riverine environment. Mar Freshw Res 60:306-316

Editorial responsibility: Brendan Godley, University of Exeter, Cornwall Campus, UK
Whitty JM, Keleher J, Ebner BC, Gleiss AC, Simpfendorfer CA, Morgan DL (2017) Habitat use of a Critically Endangered elasmobranch, the largetooth sawfish Pristis pristis, in an intermittently flowing riverine nursery. Endang Species Res 34:211-227

* Wiley TR, Simpfendorfer CA (2010) Using public encounter data to direct recovery efforts for the endangered smalltooth sawfish Pristis pectinata. Endang Species Res 12: 179-191

*Wueringer BE (2017) Sawfish captures in the Queensland Shark Control Program, 1962 to 2016. Endang Species Res 34:293-300

Submitted: November 7, 2018; Accepted: February 28, 2019 Proofs received from author(s): May 25, 2019 